López Cleries, Gloria.

FPU Universidad de Castilla-la Mancha.

Porras Soriano, Álvaro.

Universidad de Castilla-La Mancha.

\title{
EL TAG COMO CELDA DE VIGILANCIA. Una visión crítica de los metadatos y sistemas de reconocimiento facial a través de las prácticas artísticas.
}

\section{THE TAG AS A SURVEILLANCE CELL. A critical view of metadata and facial recognition systems through artistic practices.}

TIPO DE TRABAJO:

Comunicación.

PALABRAS CLAVE

panóptico, web 2.0, postinternet, biopolítica, tag

KEY WORDS

panoptic, web 2.0, postinternet, biopolitics, tag.

RESUMEN

En la actualidad la expansión de las redes sociales ha hecho posible la aparición de un nuevo modelo de vigilancia más descentralizado y más difuso. La web 2.0 y los dispositivos smartphone permiten poner en tránsito información privada a disposición de los usuarios y de empresas público - privadas que forman parte de la nueva economía de red. La cotidianización de las aplicaciones con geolocalizadores permiten almacenar todo tipo de actividades y realizar la reconstrucción de todas nuestras acciones, deseos y afectos. En un contexto de hiper-exposición, de la sociedad hiperconectada 24/7, se alza como un nuevo modelo de vigilancia más difuso, pero manteniendo el mismo efecto del Panóptico, que impacta sobre la psicología user creando un poder disciplinario ante la incertidumbre de estar en un foco de vigilancia.

La celda de aislamiento y vigilancia del Panóptico se convierte hoy no solo en cada cuenta personalizada en las redes sociales sino en toda la información que registra el historial de Google asociado a una cuenta de mail personal, a cuentas de Paypal y a infinidad de apps que registran el ritmo cardíaco, las huellas digitales, las curvas de sueño y el azúcar en la sangre. Estas aplicaciones permiten el registro total de todas las acciones y movimientos físicos, biológicos y afectivos. Desde una perspectiva foucaultiana, los medios de comunicación social son más que un vehículo para el intercambio de información, son un vehículo para la formación de la identidad y su control. 


\section{ABSTRACT.}

Nowadays, the expansion of social networks has made possible the emergence of a new surveillance model more decentralized and diffused. The web 2.0 and the smartphone devices allow to put in transit private information available to users and public-private companies that are part of the new network economy. The daily use of the applications with gps locator allows to store all kinds of activities and to carry out the reconstruction of all our actions, desires and affections. In a context of hyper-exposure, of the hyper-connected 24/7 society, it stands as a new model of more diffused surveillance, but maintaining the same effect of the Panopticon, which impacts on the user psychology creating a disciplinary power in the face of uncertainty of being in a focus of surveillance.

Panopticon's isolation and surveillance cell becomes today not only in each personalized account in social networks but in all the information that records the Google history associated with a personal email account, Paypal accounts and countless apps that register Heart rate, fingerprints, sleep curves, and blood sugar. These applications allow the total registration of all physical, biological and affective actions and movements. From a Foucaultian perspective, social media is more than a vehicle for the exchange of information, they are a vehicle for the formation of the identity and its control. 